\title{
Chemical Energy Sources Transformations by Remote Experiment
}

\author{
http://dx.doi.org/10.3991/ijoe.v10i4.3728 \\ L. Tkáć ${ }^{1}$, F. Schauer ${ }^{1,2}$ and Ž. Gerhátová ${ }^{1}$ \\ ${ }^{1}$ Trnava University in Trnava, Faculty of Education, Department of Physics, Trnava, Slovak Republic \\ 2 Tomas Bata University in Zlin, Faculty of Applied Informatics, Zlin, Czech Republic
}

\begin{abstract}
The paper describes the first experience with the set up, functioning and data evaluation of the remote experiment "Energy transformation" accessible via Internet (http://remotelab10.truni.sk ) as a part of the e-laboratory at the Department of Physics, Faculty of Education, Trnava University in Trnava, Slovakia. The remote experiment control and data acquisition is based on the system ISES (Internet School Experimental System) and its control program and www page are built using the environment Easy Remote ISES. The main goal of the experiment is the elucidation of the energy transformations of three types of well known energy sources - photovoltaic cell (solar energy to electrical energy), electrolyzer (electrical to chemical energy of hydrogen) and fuel cell (chemical energy of hydrogen to electrical energy) and finding optimal regimes for their maximum efficiencies. The perspective of the improvement of the experiment and its exploitation is given.
\end{abstract}

Index Terms - electrolyser, energy transformation, fuel cell, solar cell, remote experiment

\section{INTRODUCTION}

The energy is one of the most important physical quantities, but in the general sense it constitutes one of the most vital topics in contemporary society [1]. Surprisingly, little is known and still less is taught at all types of schools about functioning, for society vital, devices that serve as transducers of one type of the energy to another and/or means for energy storing [2].

Remote labs can expand the capability of conventional laboratories also in the field of energy transformation by increasing the number of possibilities in which a student can perform experiments $[3,4]$, while also increasing the availability of the laboratory to many students.

The purpose of the present work is the characterization of several well known energy transducers using interactive remote experiment (RE) "Energy transformation" (http://remotelab10.truni.sk). The experiment is built and located at the Trnava University in Trnava, Faculty of Education, Department of physics, as a part of Internet Natural Science Remote e-Laboratory - INRe-L [5].

The layout of the paper is following. First, we give briefly the construction of the RE with the set of energy transformation devices, followed by its technical realization and brief description of the corresponding physical basis. In the last part of the paper we show the measured data and their evaluation of the individual energy transducers, characterized by their energy transformation efficiencies (solar cell, electrolyser and fuel cell (FC)).

\section{EXPERIMENT WITH ISES}

For the building of RE Internet School Experimental System (ISES) was used [6]. ISES consists of the plug and play physical software (SW) and hardware (HW) for school experimentation. The physical HW is composed of the ISES panel and the set of easily interchangeable sensing modules and sensors (relevant details are described in [7]).

The physical HW of the RE experiment "Energy transformation" is in Fig. 1. The technical arrangement is composed of the ISES panel (1) with the set of ISES modules: 2x ISES V-meters, 2x ISES A-meters and the analogue input on the ISES panel. The physical HW include the several additional modules: photovoltaic panel JT010(17)P360x296 (2), electrolyser „VŠU-TU OSTRAVA PC001" with the solid Proton Exchange Membrane (PEM) (3), hydrogen flow meter OMEGA FMA1802 (4) and hydrogen fuel cell from NTL company DT775-1B ,inno“ (5). In the Fig. 1 is not visible the solar simulator.

To transform the hands-on experiment to RE using the communication scheme server-client we used the environment Easy Remote ISES (ER ISES) enabling the compiling of RE control program and clients web page without programming using the approach of plug and play based on the Java applets (in later versions Javscript) [8].

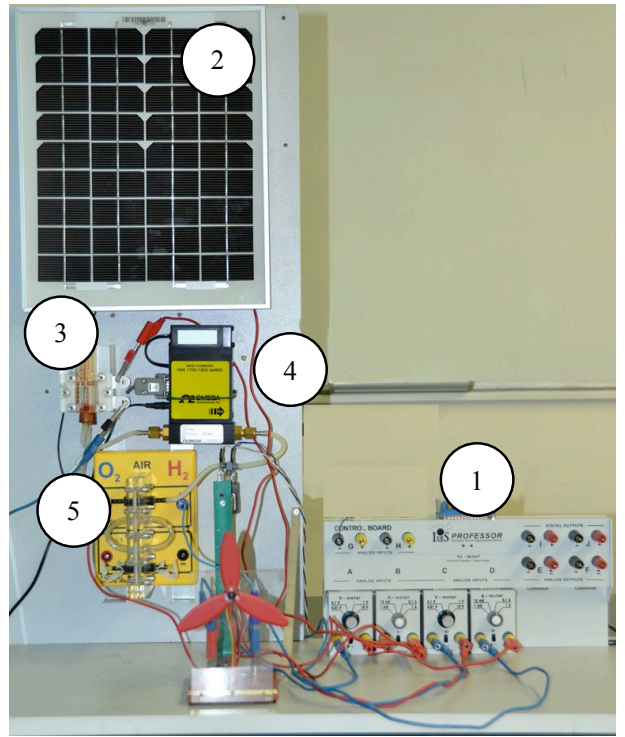

Figure 1. The layout of the experiment „Energy transformation“: (1) - ISES panel with 2xISES V-meter, 2xISES A-meter and analogue inputs (V-meter), (2) - PV panel, (3) - electrolyser, (4) - hydrogen flow meter, (5) - hydrogen fuel cell, not visible is the solar simulator 


\section{RE "ENERGY TRANSFORMATION"}

In Fig. 2 is the controlling web page of the RE „Energy transformation". The view of the life web camera is on the left side of the web page with schematical arrangement of the experiment underneath. On the right side of the web page are the control buttons for the light intensity and for the data recording. The measuring display part of the energy panel is composed of three graphical time frames of the measured signals of the individual energy transducers. The first graph shows the instantaneous value of the voltage and current from the solar cell both in the graphical and digital forms. The second graph in Fig. 2 displays the hydrogen flow time dependence. The third graph gives the voltage and current of the fuel cell. At the bottom of the web page there are the controls for the data storage to the client's PC.

\section{THEORY}

\section{A. Energy efficiency of the solar cell}

The radiant energy transformation to the electrical energy is the demanding physical process. The efficiency of this conversion is described by the relation between the maximal electrical power $\mathrm{P}_{\text {elmax }}$, to the external load (here electrolyser) and the $\mathrm{P}_{\text {radiation }}$ power

$$
\eta_{\text {photo efect }}=\frac{P_{\mathrm{el}_{\text {max }}}}{P_{\text {radiation }}} .
$$

The conversion efficiency may be expressed as a product of partial efficiencies [9]

$$
\eta_{\text {photoefect }}=\eta_{\mathrm{r}} \cdot \eta_{\mathrm{e}} \cdot \eta_{\mathrm{p}} \cdot \eta_{\mathrm{el}}=\eta_{\mathrm{r}} \cdot \eta_{\mathrm{e}} \cdot \eta_{\mathrm{p}} \cdot F F
$$

where $\eta_{\mathrm{r}}=P_{\mathrm{abs}} / P_{\mathrm{rad}}=0.70$ is the efficiency factor expressing the part of the reflected radiation (taking average reflectivity to be $0.30[10])$, defined by the quotient of the absorbed flux to the impinging flux $\left(P_{\text {rad }}=P_{\text {abs }}+P_{\text {refl }}\right), \eta_{\mathrm{e}}=1-T / T_{\text {lamp }}=0.77$ is the Carnot efficiency, $T=300 \mathrm{~K}$ and $T_{\text {lamp }}=1300 \mathrm{~K}$ is the temperature of the source; $\eta_{\mathrm{p}}=0.15$ [11] is the efficiency factor due to the loss of a part of the radiation due to the mismatch of bandgap to the spectrum of the lamp (taken as blackbody radiator at the temperature $T_{\text {lamp }}=1800 \mathrm{~K}$ ); $\eta_{\mathrm{el}}$ is the efficiency due to the cumulative electronic parameters of the cell,

$$
\eta_{\mathrm{el}}=\frac{I_{\mathrm{m}} \cdot U_{\mathrm{m}}}{I_{\mathrm{sc}} \cdot U_{\mathrm{oc}}}=F F,
$$

accessible to the measurements, where $I_{\mathrm{sc}}$ is the short circuit current of the cell, $U_{\mathrm{oc}}$ is the open circuit voltage, $F F$ is the fill factor and $U_{\mathrm{m}}, I_{\mathrm{m}}$ are the voltage and current for the maximum electrical power.

\section{B. Efficiency of the Electrolyser}

Electrical energy obtained in the first energy transformation step (solar energy $\rightarrow$ electrical energy) is transformed in the following step into the chemical energy in the form of hydrogen and oxygen by the process of electrolysis. The principal part of the experiment is the proton exchange membrane (PEM) of the electrolysis unit.

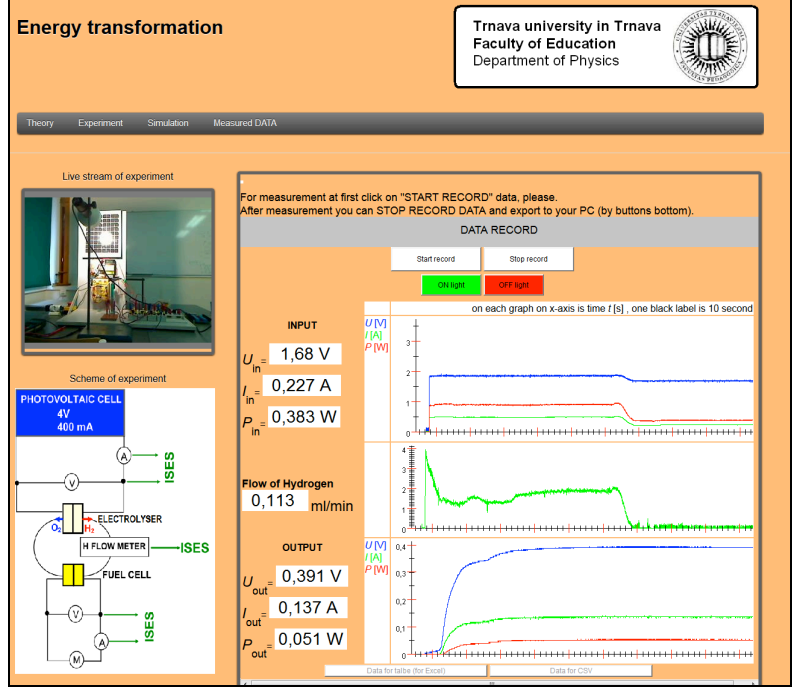

Figure 2. Web page of the remote experiment "Energy transformation" see URL: http://remotelab10.truni.sk

The following reaction occurs in the electrolyser:

$$
\mathrm{H}_{2} \mathrm{O}_{(\mathrm{l})} \rightarrow \mathrm{H}_{2(\mathrm{~g})}+0.5 \mathrm{O}_{2(\mathrm{~g})} .
$$

In electrolysis, the applied voltage must be at least as large as theoretical cell voltage in order for a current to flow. Hence, from mentioned facts we can calculate the theoretical value of this voltage from the free enthalpy of reaction $\Delta G\left(F-\right.$ Faraday's charge $\left.\left(\mathrm{C} \cdot \mathrm{mol}^{-1}\right)\right)$

$$
\Delta U_{\text {st }}=\frac{\Delta G_{298 \mathrm{~K}}}{2 F}==1.23 \mathrm{~V} .
$$

From the point of view of the thermal balance it is important to know the value of threshold voltage of the cell

$$
U_{\mathrm{tr}}=\frac{\Delta H_{298 K}}{2 F}=1.48 \mathrm{~V},
$$

where $\Delta H_{298 \mathrm{~K}}=2.8626 \cdot 10^{5} \mathrm{~J}$ is the molar reaction enthalpy and the enthalpy of reaction is $\Delta G_{298 \mathrm{~K}}=2.3736 \cdot 10^{5} \mathrm{~J}$. Up to this voltage (6) the electrolyser works without heat generation and when exceeded, the electrolyser starts to produce heat and its efficiency drops. The efficiency of the electrolyser with respect to the delivered electrical energy per unit time (power $P_{\mathrm{PV}}$ ) is defined

$$
\eta_{\text {electrolysis }}=\frac{E_{V \text { of } \mathrm{H}_{2}}}{E_{\mathrm{PV}}}
$$

where $E_{\mathrm{V} \text { of } \mathrm{H}_{2}}$ - combustion energy of produced $\mathrm{H}_{2}(\mathrm{~J})$ per time unit and the $E_{\mathrm{PV}}$ - electrical energy from PV panel (J) per time unit.

\section{Efficiency of the Fuel cell}

In the fuel cell the chemical energy of the hydrogen and oxygen is directly converted via chemical reaction into electrical energy. Hydrogen and oxygen react to form water, giving up free charge carriers and the heat 
PAPER

CHEMICAL ENERGY SOURCES TRANSFORMATIONS BY REMOTE EXPERIMENT

$$
\begin{gathered}
\mathrm{H}_{2} \rightarrow 2 \mathrm{H}^{+}+2 \mathrm{e}^{-}, \\
\mathrm{O}_{2}+2 \mathrm{H}^{+}+2 \mathrm{e}^{-} \rightarrow \mathrm{H}_{2} \mathrm{O} .
\end{gathered}
$$

The maximum theoretical efficiency of the fuel cell $\eta_{\mathrm{FC} \max }$ is

$$
\eta_{\mathrm{FC} \max }=\frac{\Delta G_{298}}{\Delta H_{298}}=\frac{2.3736 \cdot 10^{5}}{2.8626 \cdot 10^{5}}=0.83,
$$

The efficiency of the fuel cell with respect to the produced $\mathrm{H}_{2}$ by electrolyser, may be defined by two efficiencies, the electrical efficiency $\eta_{\mathrm{FC}-\mathrm{el}}$ and the chemical efficiency (also referred as Faraday's) $\eta_{\text {FC-chem }}$ of the generated hydrogen

$$
\begin{gathered}
\eta_{\mathrm{FC}-\mathrm{el}}=\frac{E_{e l}}{E_{V \text { of } \mathrm{H}_{2}}}, \\
\eta_{\mathrm{FC}-\text { chem }}=\frac{V_{t h}}{V_{\exp }},
\end{gathered}
$$

where $E_{\mathrm{el}}-$ electrical energy supplied to the load per time unit, $E_{\mathrm{V} \text { of } \mathrm{H} 2}-$ energy content of hydrogen per time unit, $V_{\text {th }}$ - theoretical volume of produced $\mathrm{H}_{2}, V_{\exp }$ - measured volume of produced $\mathrm{H}_{2}$.

\section{RESUlts}

\section{A. Efficiency of the solar cell}

Maximum electrical power $P_{\mathrm{el}}$ of the PV panel as determined from the data in Fig. 3 is

$$
P_{\mathrm{el} \max }=U_{\mathrm{m}} \cdot I_{\mathrm{m}}=1.67 \mathrm{~W},
$$

and corresponding current and voltage for the maximum electrical power $I_{\mathrm{m}}=0.456 \mathrm{~A}$ and $U_{\mathrm{m}}=3.63 \mathrm{~V}$.

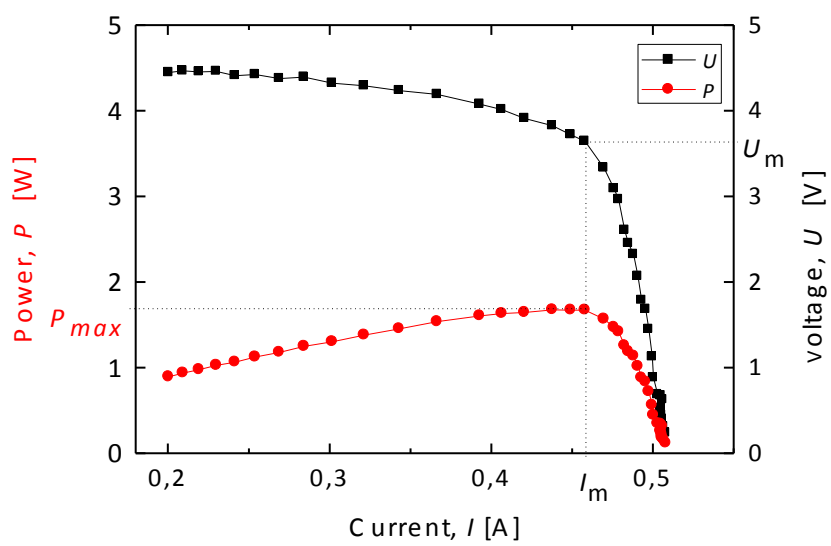

Figure 3. $I-V$ characteristic of the solar panel (black), the output power $P$ vs. Current $I$ (red)

Also visible in Fig. 3 are the values of the short-circuit current $I_{\mathrm{sc}}=0.51 \mathrm{~A}$ and open circuit voltage $U_{\mathrm{oc}}=4.45 \mathrm{~V}$. The corresponding fill factor determined according (3), is $F F=0.73$ and the total conversion efficiency of the measured solar cell is thus

$$
\eta_{\text {photoef. }}=\eta_{\mathrm{r}} \cdot \eta_{\mathrm{e}} \cdot \eta_{\mathrm{p}} \cdot \eta_{\mathrm{el}}=0.7 \cdot 0.83 \cdot 0.15 \cdot 0.73=0.063
$$

\section{B. Efficiency of the electrolyser}

The efficiency of the electrolyser can be calculated using (7) where value of $E_{\mathrm{PV}}$ (electrical power from PV panel) calculated as the integral of power supply $\left(P_{\mathrm{el}}\right.$ in Fig. 4) from PV panel during $t=1 \mathrm{~min}$

$$
E_{\mathrm{PV}}=\int_{t=1 \min } P_{e l} \mathrm{~d} t=22.98 \mathrm{~J} .
$$

The value of $E_{\mathrm{V} \text { of } 2}$ is determined from Fig. 4 by $\Phi_{0}$

$$
E_{V \text { of } \mathrm{H}_{2}}=\frac{V_{\text {produced. }}}{V_{\text {molar }}} \cdot \Delta H_{298}=18.24 \mathrm{~J} \text {, }
$$

where $\quad V_{\text {produced }}=\frac{\Phi_{0}}{t}=1.53 \mathrm{ml} / \mathrm{min}, \quad V_{\text {molar }}-$ molar volume of $\mathrm{H}_{2}$ (for $T=298 \mathrm{~K}$ is $V_{\text {molar }}=24000 \mathrm{ml} / \mathrm{mol}$ ), and $\Delta H_{298 \mathrm{~K}}$ molar reaction enthalpy $\Delta H_{298 \mathrm{~K}}=2.8626 \cdot 10^{5} \mathrm{~J}$. Then the efficiency of the electrolyser is

$$
\eta_{\text {electrolysis }}=\frac{E_{V \text { of } \mathrm{H}_{2}}}{E_{\mathrm{PV}}}=\frac{18.24}{22.98}=0.79
$$

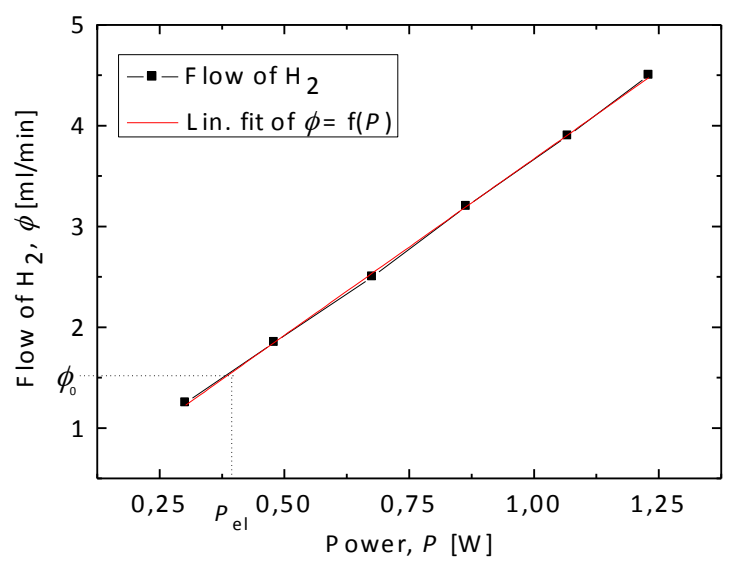

Figure 4. Dependence of Flow of $\mathrm{H}_{2}$ per min $\left(V_{\text {exp }}\right)$ on electric power delivered $P_{\mathrm{el}}$ from PV panel

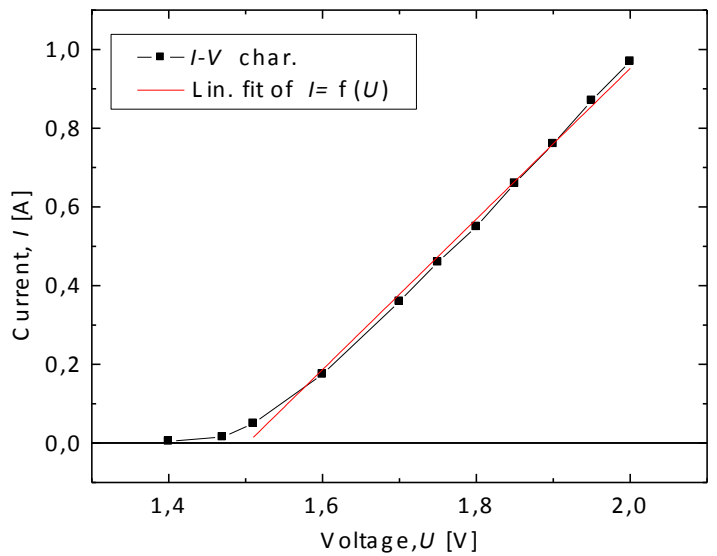

Figure 5. $I-V$ characteristic line of a PEM electrolyser

The energy efficiency of the fuel cell may be described by two efficiencies as mentioned in 4.1 . The first is the 
electrical efficiency $\eta_{\mathrm{FC}-\mathrm{el}}$ as the ratio of the electrical energy produced by FC to the energy contained in delivered hydrogen. The energy content of hydrogen is calculated by using the amount of energy evolved when hydrogen is combusted. This is $2.8626 \cdot 10^{5} \mathrm{~J} / \mathrm{mol}$ of $\mathrm{H}_{2}$ $\left(\Delta H_{298 \mathrm{~K}}=2.8626 \cdot 10^{5} \mathrm{~J}\right)$. Electrical energy gives the required value of electrical power in time of measurement. The calculating is for the time of measurement $t=1 \mathrm{~min}$, and energy content of consumed $\mathrm{H}_{2}$ calculate as

$$
\eta_{\mathrm{FC}-\mathrm{el} l}=\frac{E_{e l}}{E_{V \text { of } \mathrm{H}_{2}}}=\frac{\int_{t=1 \mathrm{~min}} P_{e l} \mathrm{~d} t}{\frac{V_{\text {consumed }}}{V_{\text {molar }}} \cdot \Delta H_{298}}=0.18,
$$

where $V_{\text {produced }}=\frac{\Phi_{0}}{t}=1.53 \mathrm{ml}, V_{\text {molar }}-$ molar volume of $\mathrm{H}_{2}$ (for $T=298 \mathrm{~K}$ is $V_{\text {molar }}=24000 \mathrm{ml} / \mathrm{mol}$ ), $P_{\mathrm{el}}-$ electrical power of $\mathrm{FC}(\mathrm{W})$.

The second efficiency - Faraday efficiency $\left(\eta_{\text {FC-chem }}\right)$ is the ratio between the theoretically calculated volume $\left(V_{\mathrm{th}}\right)$ of hydrogen consumed by $\mathrm{FC}$ and the experimentally calculated volume of hydrogen consumed $\left(V_{\text {exp }}\right)$. At the standard pressure and temperature, the volume of $\mathrm{H}_{2}$ is $24000 \mathrm{ml} / \mathrm{mol}$. The electrical charge of one mole of electrons is given as $96500 \mathrm{C}$. Since there are two moles of electrons involved, the electrical charge deliver by one $\mathrm{mol}$ of $\mathrm{H}_{2}$ is $96500 \mathrm{C} \times 2=193000 \mathrm{C}$.

$$
\eta_{\mathrm{FC}-\mathrm{chem}}=\frac{V_{\mathrm{th}}}{V_{\text {exp }}}=\frac{\frac{\int_{t=1 \mathrm{~min}} Q \mathrm{~d} t}{Q_{1 \mathrm{~mol}}} \cdot V_{\text {molar }}}{V_{\exp }}=0.67 .
$$

Fig. 6 gives the dependence of the output power from the fuel cell on the external resistance $R$ for the finding of the ideal external load $R_{0}$.

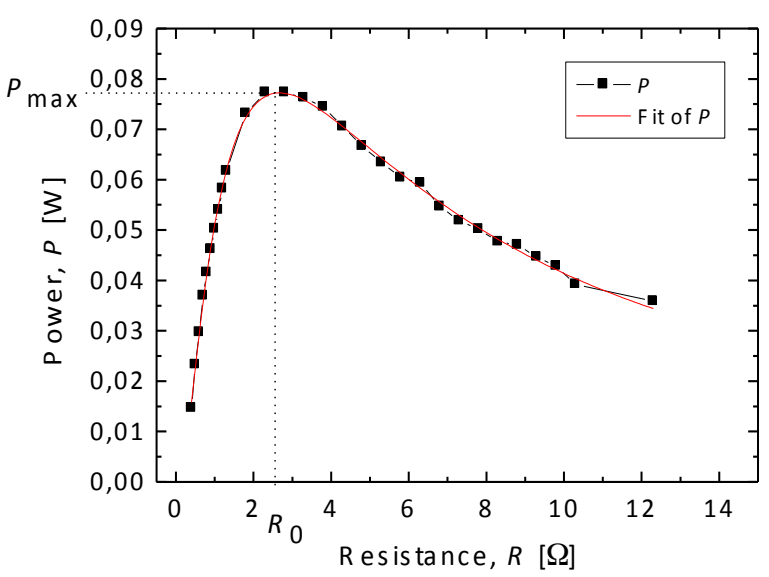

Figure 6. The delivered power $P$ vs. load resistance $R$ dependence of FC; ideal value of external load $R_{0}=2.59 \Omega$

Fig. 7 shows the dependence of the FC voltage $U$ (black) and the FC power $P$ (red) on the current $I$ to the load.

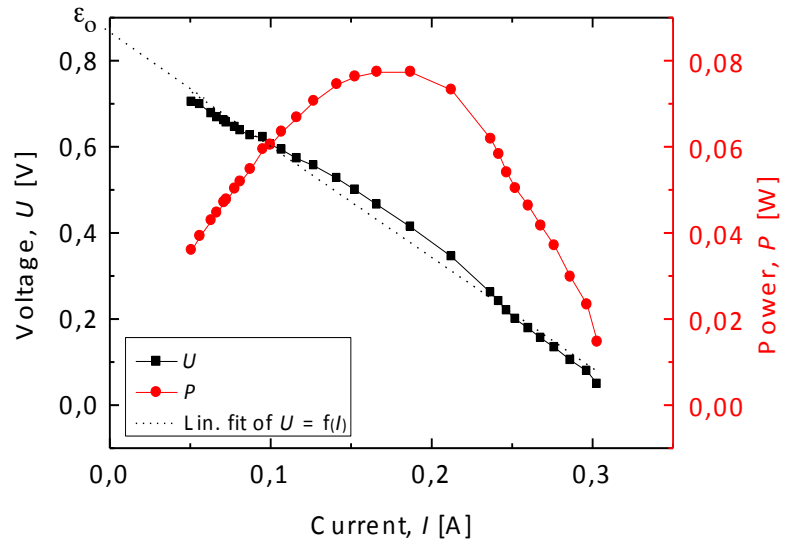

Figure 7. The dependence of the FC voltage $U$ (black) and the FC power $P$ (red) on the current $I$ to the load

\section{NEXT WORK}

At the present stage of the remote experiment "Energy transformation" the remote experimentators study the energy transformation of the photovoltaic panel at the fixed illumination at several predetermined light intensities. In the next development of the experiment we intend to build in the rotation of the light source and continuous change of irradiation of the photovoltaic panel as a next parameter for optimizing the experiment. Thus, the hydrogen output and working regime of fuel cell may be studied and optimized.

\section{CONCLUSIONS}

1. Experiment and experimentation is a vital component of any science subject. In spite of this the experimentation at starting courses of universities and secondary schools is limited for different reasons, lack of time and experimental equipment, to mention two predominant $[12$, 13]. This is the reason for building management systems for remote laboratories (RLMS [14]), that bring to the teacher the RE in question removing both obstacles.

2. RE "Energy transformation" aims at the free accessible remote experimentation in the field of energy and its transformations with the possibilities to demonstrate the physical phenomena involved.

3. By RE "Energy transformation" the teachers can show three typical energy transformations solar energy $\rightarrow$ electrical energy (photovoltaic cell), electrical energy $\rightarrow$ chemical energy (water electrolyser) and chemical energy $\rightarrow$ electrical energy (fuel cell).

4. Envisaged changes of the experiment increase the range of possibilities to study and measure energy transformations of the individual energy sources in a wider range of parameters.

5. On top of this RE "Energy transformation" may be with advantage used in the laboratory exercise to determine the energy conversion of individual energy transducers, as every process of the energy transformation is with the data outputs, enabling work with and processing of the corresponding data towards the assignment - finding conversion efficiencies of all energy transducers in RE. 
6. RE "Energy transformation" may be with advantage used for basic courses of physics and sciences subjects at Universities [15] and also is suitable for the secondary school level [16]. It may be used for distance education students and students of Open universities [17].

\section{ACKNOWLEDGMENT}

Paper was published thanks to the Grant of the Trnava University in Trnava No. 10/TU/13 "Energy in the teaching of the physics with using the remote experiment", grant agency APVV project No. APVV 0096-11 and grant agency KEGA No 011TTU-4/2012 and 020TTU-4/2013.

\section{REFERENCES}

[1] A. V. Herzog, T. E. Lipman, and D. M. Kammen, "Renewable energy sources," in Encyclopedia of Life Support Systems (EOLSS). Forerunner Volume-'Perspectives and Overview of Life Support Systems and Sustainable Development, 2001, Island press, ISBN 1-55963-139-2.

[2] F. Schauer, Ž. Gerhátová, L. Tkáč, "ENERGY - remote experiment on characterization of energy sources," in Multimedia in physics teachings and learning, Madrid, Spain: EPS, 2013, p. 48

[3] G. Canfora, P. Daponte, and S. Rapuano, "Remotely Accessible Laboratory for Electronic Measurement Teaching," in Comput. Standards and Interfaces, vol. 26, no. 6, 2004, pp. 489-499. http://dx.doi.org/10.1016/j.csi.2004.03.001

[4] F. Schauer, M. Ožvoldová, L. Tkáč, "INTe-L: wide open door for education by remote and virtual experiments exemplified on electricity, magnetism and electromagnetism," in IT innovative practices in secondary schools. - Bilbao: University of Deusto, 2013, pp. 205-251, ISBN 978-84-15759-16-4.

[5] M. Ožvoldová, F. Schauer, P. Čerňanský, Ž. Gerhátová, L. Tkáč, and M. Beňo, "1st Slovak Internet Natural Sciences Remote eLaboratory (INRe-L)," in Proceedings of the conference REV2010-Remote Engineering \& Virtual Instrumentation, 2010, pp. 313-319.

[6] ISES. (2014, January 10). Available: www.ises.info.

[7] F. Schauer, F. Lustig, and M. Ožvoldová, "ISES - Internet School Experimental System for Computer-Based Laboratories in Physics," in Innovations 2009: World Innovations in Engineering Education and Research, W. Aung, et al. (eds.), iNEER, Arlington, VA, 2009, Chap. 10, pp. 109-118.

[8] M. Krbeček, F. Schauer, and F. Lustig. "Easy Remote ISES Environment for Remote Experiments Programming," in Innovations 2013: World Innovations in Engineering Education and Research, W. Aung, et al. (eds.), iNEER, Potomac, MD, USA, pp. $80-101$.

[9] F. Schauer, F. Lustig, and M. Ožvoldová, "Remote materials science internet experiments: solid state photovoltaic cell characterization," in Journal of Materials Education, vol. 29, no. 3-4, 2007, pp. 193-200.,

[10] J. R. Chelikowsky, and M. L. Cohen, Phys. Rev. B14, 556-582, 1976. http://dx.doi.org/10.1103/PhysRevB.14.556

[11] R. Bonnefille, and J. Robert, "Principes generaux des convertisseurs directs d energie," Dunod, Paris, 1971.

[12] S. Gröber, M. Vetter, B. Eckert and H. J. Jodl, "Experimenting from a Distance - Remotely Controlled Laboratory RCL," Eur. J. Phys., vol. 28, no. 3, 2008, p. 127. http://dx.doi.org/10.1088/0143$\underline{0807 / 28 / 3 / \mathrm{S} 12}$

[13] K. Azad, M. Auer, J. Harward, "Internet Accessible Remote Laboratories: Scalable E-Learning Tools for Engineering and Science Disciplines," IGI Global (701 E. Chocolate Avenue, Hershey, Pennsylvania, 17033, USA), 2012, ISBN 978-1-61350186-3.

[14] F. Schauer, et al., "REMLABNET - open remote laboratory management system for e-experiments," in 2014 11th International Conference on Remote Engineering and Virtual Instrumentation (REV), Polytechnic of Porto (ISEP) in Porto, Portugal, 26-28 February 2014, ISBN 978-4799-2025-9, pp. 268-273.

[15] L. Domingues, I. Rocha, F. Dourado, M. Alves, and E. C. Ferreira, "Virtual laboratories in (bio) chemical engineering education," in Education for Chemical Engineers, vol. 5, no. 2, 2010, pp. 22-27. http://dx.doi.org/10.1016/j.ece.2010.02.001

[16] M. Ožvoldová, Ž. Gerhátová, "Energy and its transformation primary school project based education using integrated elearning," In: Procedia - social and behavioral sciences. vol. 89, no. 1, 2013, pp. 5-9, ISSN 1877-0428.

[17] A. Rosa, "The challenge of instructional laboratories in distance education," in ABET Annual Meeting, Baltimore, MD: ABET, 2003.

\section{AUTHORS}

L. Tkáč with the Trnava University in Trnava, Faculty of Education, Trnava University in Trnava, Priemyselná 4, SK-91843, Trnava, Slovak Republic (e-mail: tkac.lucas@gmail.com),

F. Schauer is with the Trnava University in Trnava, Faculty of Education, Priemyselná 4, SK- 918 43, Trnava, Slovak Republic, and Tomas Bata University in Zlin, Faculty of applied informatics, T.G. Masaryk sq. 275, Zlín CZ-76272, Czech Republic (e-mail: fschauer@fai.utb.cz ),

Ž. Gerhátová is with the Trnava University in Trnava, Faculty of Education, Trnava University in Trnava, Priemyselná 4, SK- 918 43, Trnava, Slovak Republic (email: gerhatova.zaneta@truni.sk).

Submitted 31 March 2014. Published as re-submitted by the authors 08 June 2014. 